\title{
DEVELOPMENT OF FLOW CYTOMETRY-BASED ALGAL BIOASSAYS FOR ASSESSING TOXICITY OF COPPER IN NATURAL WATERS
}

\author{
Natasha M. Franklin, $* \dagger \neq$ Jennifer L. Stauber, $\dagger$ and Richard P. Lim $\ddagger$ \\ $\nmid$ Centre for Advanced Analytical Chemistry, CSIRO Energy Technology, PMB 7. Bangor. New South Wales 2234, Australia \\ $\ddagger$ Department of Environmental Sciences, University of Technology, Sydney, PO Box 123, Broadway, New South Wales 2007, Australia
}

(Received 24 September 1999; Accepted 12 May 2000)

\begin{abstract}
Copper toxicity to the freshwater algae Selenastrum capricornutum and Chlorella sp. and the marine algae Phaeodactylum tricornutum and Dunaliella tertiolecta was investigated using different parameters measured by flow cytometry: cell division rate inhibition, chlorophyll $a$ fluorescence, cell size (i.e., light-scattering), and enzyme activity. These parameters were assessed regarding their usefulness as alternative endpoints for acute ( $1-24 \mathrm{~h})$ and chronic (48-72 h) toxicity tests. At copper concentrations of $10 \mu \mathrm{g} / \mathrm{L}$ or less, significant inhibition $(50 \%)$ of the cell division rate was observed after 48 - and 72 -h exposures for Chlorella sp., S. capricornutum, and P. tricornutum. Bioassays based on increases in algal cell size were also sensitive for Chlorella sp. and $P$. tricornutum. Copper caused both chlorophyll a fluorescence stimulation (48-h EC50 of $10 \pm 1 \mu \mathrm{g} \mathrm{Cu} / \mathrm{L}$ for $P$. tricornutum) and inhibition (48-h EC50 of $14 \pm 6 \mu \mathrm{g} \mathrm{Cu} / \mathrm{L}$ for $S$. capricornutum). For acute toxicity over short exposure periods, esterase activity in $S$. capricornutum using fluorescein diacetate offered a rapid alternative (3-h EC50 of $90 \pm 40 \mu \mathrm{g} \mathrm{Cu/L}$ ) to growth inhibition tests for monitoring copper toxicity in mine-impacted waters. For all the effect parameters measured. $D$. tertiolecta was tolerant to copper at concentrations up to its solubility limit in seawater. These results demonstrate that flow cytometry is a useful technique for toxicity testing with microalgae and provide additional information regarding the general mode of action of copper (II) to algal species.
\end{abstract}

Keywords-Algae Copper Flow cytometry Toxicity Bioassay

\section{INTRODUCTION}

Toxicity tests based on growth inhibition of local species of algae and bacteria have been used, in conjunction with invertebrate and fish tests, to assess the environmental impact of contaminants in discharges to marine and freshwaters. Laboratory toxicity data have been used in ecological risk assessments, to derive water- and sediment-quality guidelines, to investigate the bioavailability of contaminants, and to establish cause-effect relationships for particular toxicants. Various standard growth inhibition tests use algae $[1,2]$; these tests expose exponentially growing cells to different concentrations of a toxicant during a 3- to 4-d period. Although such growth inhibition tests are sensitive, reproducible, and use an ecologically relevant endpoint, these single-species laboratory tests have several limitations [3]

Standard algal bioassays measure only one toxicological endpoint per test, typically growth rate or cell yield, from which little information can be gained regarding the mechanisms of toxicity of contaminants. These bulk populationbased endpoints sacrifice information regarding the distribution of responses among individual cells within a population by providing the average response to a toxicant. One limitation of algal growth inhibition bioassays in particular involves the method of counting algal cells. Because microscope counting is too labor-intensive, particle counters such as Coulter Counters $^{\circledR}$ (Beckman-Coulter, Fullerton, CA, USA) are used; however, these cannot distinguish between live or dead algal cells. The technique of flow cytometry can be used to address these limitations.

Flow cytometry is a rapid method for the quantitative mea-

* To whom correspondence may be addressed

(natasha.franklin@det.csiro.au). surement of individual cells in a moving fluid [4]. This technique has the ability to measure thousands of cells per second, and it can perform multiparameter analysis on a wide range of cellular properties by measurement of algal light-scatter signals and autofluorescence [5]. Through use of biochemically specific fluorescent dyes, flow cytometry can also provide additional information regarding the physiological condition of cells [6]. Flow cytometry has sufficient sensitivity to analyze cell densities as low as $10^{2} \mathrm{cells} / \mathrm{ml}$, and it has an advantage over conventional counting techniques in that it can differentiate live from dead algal cells and other particles on the basis of chlorophyll $a$ fluorescence (i.e., autofluorescence). By exploiting the optical characteristics of individual cells, flow cytometry also has the ability to analyze heterogeneous or natural algal populations [7].

One of the major applications of flow cytometry to environmental studies has been in the fields of oceanography and algal ecology, where it has been used to quantify and sort different taxonomic classes of algae based on their different photosynthetic pigments and light-scattering properties $[4,7]$. More recently, flow cytometry has been applied to physiological studies with algae, bacteria, and yeasts. Examples include cell viability analysis using fluorescein diacetate (FDA) to measure esterase activity [8] and membrane potential analysis using the cationic dye 3,3'-dihexyloxacarbocyanine $\left(\mathrm{DiOC}_{6}[3]\right)[9,10]$. Flow cytometric techniques have important advantages over conventional biochemical assays, because cell functions can be quickly determined at conditions close to the in vivo state [9].

The potential for flow cytometry as a tool in ecotoxicological studies has not yet been fully explored. A preliminary study by Premazzi et al. [7] investigated the effect of trace 
Table 1. Culture conditions for algal stock culture maintenance and toxicity tests

\begin{tabular}{|c|c|c|c|c|}
\hline Alga & $\begin{array}{l}\text { Temperature, } \\
{ }^{\circ} \mathrm{C}\end{array}$ & $\begin{array}{l}\text { Light }^{\mathrm{a}}(\mu \mathrm{mol} \\
\left.\text { photons } / \mathrm{m}^{2} / \mathrm{s}\right)\end{array}$ & $\begin{array}{l}\text { Light/dark } \\
\text { cycle }\end{array}$ & Culture medium \\
\hline \multicolumn{5}{|l|}{ Stock maintenance } \\
\hline Chlorella sp. & 27 & 75 & $12: 12$ & $\mathrm{JM} / 5[21]$ \\
\hline S. capricornutum & 24 & 68 & $24: 0$ & US EPA medium [2] \\
\hline P. tricornutum & 21 & 72 & $12: 12$ & $\mathrm{f} / 2[22]$ \\
\hline D. tertiolecta & 21 & 44 & $12: 12$ & $\mathrm{f} / 2[22]$ \\
\hline \multicolumn{5}{|l|}{ Toxicity tests } \\
\hline Chlorella sp. & 27 & 137 & $12: 12$ & $\begin{array}{l}\text { Synthetic softwater }+15 \\
\mathrm{mg} / \mathrm{L} \mathrm{NO} \mathrm{NO}_{3}^{-}+0.15 \mathrm{mg} / \mathrm{L} \mathrm{PO}_{4}^{3-} \\
\text { US EPA without EDTA }{ }^{\mathrm{b}}[2]\end{array}$ \\
\hline S. capricornutum & 24 & 68 & $24: 0$ & Filtered seawater +15 \\
\hline P. tricornutum & 21 & 139 & $12: 12$ & $\begin{array}{l}\mathrm{mg} / \mathrm{L} \mathrm{NO}_{3}+1.5 \mathrm{mg} / \mathrm{L} \mathrm{PO}_{4} \\
\text { Filtered seawater }+15\end{array}$ \\
\hline D. tertiolecta & 21 & 139 & $12: 12$ & $\mathrm{mg} / \mathrm{L} \mathrm{NO} \mathrm{N}_{3}+1.5 \mathrm{mg} / \mathrm{L} \mathrm{PO}_{4}$ \\
\hline
\end{tabular}

"Philips TL 40W cool white fluorescent lighting.

b U.S. EPA = U.S. Environmental Protection Agency; EDTA = ethylenediaminetetraacetic acid.

metals and nitrilotriacetic acid on mixed algal populations. This work, however, primarily focused on correlating cell size and cell number measurements obtained by flow cytometry with those obtained by conventional counting techniques of microscopy and Coulter counting. Other groups [9,11-13] demonstrated the usefulness of flow cytometry in algal physiological studies by investigating the effect of copper on cell size, chlorophyll $a$ fluorescence, enzyme activity, intracellular $\mathrm{pH}$, and membrane potential in the marine diatom Phaeodactylum tricornutum. However, most of these studies used unrealistically high metal concentrations ( $\geq 28 \mathrm{mg} \mathrm{Cu} / \mathrm{L}$ ) to obtain a response, and the usefulness of these multiple endpoints for routine toxicity testing was not investigated. More recently, Blaise and Ménard [14] used flow cytometry to develop a freshwater-sediment toxicity test based on esterase inhibition in Selenastrum capricornutum.

The main objective of the present study was to investigate the suitability of flow cytometry as a tool for toxicity testing with marine and freshwater algae. Toxicity tests with two marine algae, Dunaliella tertiolecta and $P$. tricornutum, and two freshwater green algae, $S$. capricornutum and a tropical Chlorella sp., were developed based on inhibition of growth, chlorophyll $a$ fluorescence and esterase activity, and changes in cell size and granularity. Growth inhibition tests have been widely used with these species because of their ubiquitous distribution, sensitivity, and availability as axenic cultures. The relative sensitivities of the various flow cytometric parameters were evaluated for their usefulness as routine toxicity test endpoints.

The second objective of the present study was to utilize the multiple endpoints that are measurable by flow cytometry to further investigate mechanisms of toxicity of copper to microalgae. Results of previous research indicate that copper binds rapidly to algal cell surface sites, followed by slower uptake through the membrane by facilitated diffusion. Effects of copper on algal cell membrane permeability have previously been reported [15]. After transport into the cystol, copper may oxidize sulfhydryl groups, leading to a lowered ratio of reduced to oxidized glutathione and subsequent inhibition of cell division [16]. Copper may also affect subcellular organelles such as the chloroplast and mitochondria. Wong et al. [17] reported structural alterations to thylakoid membranes in the chloroplast of Chlorella cells, and inhibition of photosynthesis has also been observed [13,16]. In addition, copper may exert its toxicity by disrupting the production of adenosine triphosphate (ATP) [13] or by inactivating several enzymes, such as catalase [16], $\beta$-D-galactosidase [18], and esterase [19]. Copper was chosen as the reference toxicant in this study, because it is a common pollutant from urban, industrial, and mining inputs into aquatic systems and because it is one of the most toxic metals to microalgae [20].

\section{MATERIALS AND METHODS}

\section{Algal cultures}

Dunaliella tertiolecta Butcher (strain CS175) was obtained from the Commonwealth Scientific and Industrial Research Organization Microalgae Culture Collection Hobart, Tasmania, Australia. The marine diatom $P$. tricornutum Bohlin was obtained from the National Research Centre Istituto di Biofisica, Pisa, Italy. The freshwater green alga $S$. capricornutum (more recently called $P$ seudokerchnerella subcapitata) was obtained from the American Type Culture Collection, Maryland, USA. Chlorella sp. was isolated from Lake Aesake, Strickland River, Papua New Guinea, and cultured in JM/5 media [21]. Axenic cultures of all species were maintained as described in Table 1.

\section{Toxicity tests}

Culture conditions for the toxicity tests are shown in Table 1. For the marine species $D$. tertiolecta and $P$. tricornutum, f/2 medium [22] was replaced with filter-sterilized seawater supplemented only with nitrate $\left(15 \mathrm{mg} \mathrm{NO}_{3}^{-} / \mathrm{L}\right)$ and phosphate (1.5 $\mathrm{mg} \mathrm{PO}_{4}{ }^{3-} / \mathrm{L}$ ) to maintain exponential growth over $72 \mathrm{~h}$ For $S$. capricornutum, the test medium consisted of the standard U.S. Environmental Protection Agency media without ehtylenediaminetetraacetic acid, with an alkalinity of $9 \mathrm{mg}$ $\mathrm{CaCO}_{3} / \mathrm{L}$ [2]. For Chlorella sp., a synthetic soft water [2] having a water hardness of 80 to $90 \mathrm{mg} \mathrm{CaCO}_{3} / \mathrm{L}$ and an alkalinity of $54 \mathrm{mg} \mathrm{CaCO} / \mathrm{L}$ was supplemented with nitrate $\left(15 \mathrm{mg} \mathrm{NO}{ }_{3}-/ \mathrm{L}\right)$ and phosphate $\left(0.15 \mathrm{mg} \mathrm{PO}_{4}{ }^{3-} / \mathrm{L}\right)$. Static culture conditions were maintained throughout the tests.

Copper stock solutions ( 5 and $100 \mathrm{mg} / \mathrm{L}$ ) were prepared from copper sulfate $\left(\mathrm{CuSO}_{4} 5 \mathrm{H}_{2} \mathrm{O}\right)$ and acidified to a $\mathrm{pH}$ of less than 2 by the addition of $\mathrm{HCl}$. Controls, together with at least five metal concentrations (each in triplicate), were prepared. Fifty milliliters of toxicity test medium was dispensed 
into $250-\mathrm{ml}$ borosilicate glass Erlenmeyer flasks that were precoated with a silanizing solution (Coatasil, Ajax Chemicals, Auburn, NSW, Australia) to reduce adsorption of metals to the flask walls. All glassware was acid-washed in $10 \%$ concentrated $\mathrm{HNO}_{3}$ before use. Subsamples $(5 \mathrm{ml})$ were immediately taken from each flask and acidified before determination of total dissolved copper by graphite furnace atomic absorption spectrometry (Perkin-Elmer Model 4100ZL, Norwalk, CT, USA). Measured copper concentrations were used to calculate toxicity endpoints.

Exponentially growing cells of all species were centrifuged and washed three times and then resuspended in either seawater or Milli-Q water (Bedford, MA, USA) as appropriate. Each flask was inoculated with 2 to $4 \times 10^{4}$ cells $/ \mathrm{ml}$ of the prewashed algal suspension. Samples were incubated under the conditions described in Table 1, and subsamples obtained after $1,3,24,48$, and $72 \mathrm{~h}$ for flow cytometry. Temperature, $\mathrm{pH}$, and salinity were monitored throughout the test.

\section{Flow cytometric analysis}

In each toxicity test, multiple effect parameters, including cell size, cell shape, chlorophyll $a$ fluorescence, and cell division rate (i.e., growth rate), were determined simultaneously using a Bio-Rad Bryte HS Flow Cytometer (Richmond, CA, USA) equipped with an xenon-ion excitation lamp (488 nm). The flow cytometer hydrodynamically focuses cells into a fluid stream so that the cells pass individually through the light source. Two light-scatter detectors identify the morphology of the cell. The forward-angle light scatter (LS1 $<15^{\circ}$ ) detector provided data on cell size, whereas the side-angle light scatter (LS2 $=15-85^{\circ}$ ) detector provided information on cell size/ shape. Shifts in light-scatter properties were measured by determining the percentage shift of cells out of the control region (set at $95 \%$ of the population) at each copper concentration.

\section{Fluorescence measurements}

Fluorescence was collected at a range of wavelengths by three-color photomultiplier tubes with fluorescence-emission filters (FL1, 530-560 nm; FL2, 560-590 nm; FL3, 660-700 $\mathrm{nm})$. Fluorescein fluorescence was detected as green fluorescence in FL1, membrane potential changes as orange fluorescence in FL2, and chlorophyll $a$ or auto-fluorescence as red fluorescence in FL3. For each effect parameter (e.g., esterase activity, membrane potential, and chlorophyll $a$ fluorescence) shifts were determined by defining three fluorescence states (S1, S2, S3) on the histogram of cell number versus fluorescence. State S2 was set on the distribution of healthy control cells, whereas $S 1$ (i.e., the remaining area of the histogram to the left of S2) and S3 (i.e., the remaining area of histogram to the right of S2) indicated decreased and increased fluorescence, respectively. Toxicity was expressed as a percentage shift of cells out of the control region (S2) and into either the S1 (i.e., fluorescence inhibition) or \$3 (i.e., fluorescence stimulation) region.

Nonalgal particles and dead cells were excluded from the analysis by setting an acquisition threshold on FL3 (positioned to the left of the distribution of healthy control cells). To investigate shifts in chlorophyll $a$ fluorescence, however, the acquisition threshold was set on LS1 (i.e., cell size) so that both increases and decreases in red autofluorescence could be observed. For all other effect parameters simultaneously measured using the LS1 threshold, cells were gated by the FL3 distribution of the control population. Data were collected and displayed in one-dimensional histograms comprising 256 channels and two-dimensional cytograms comprising $64 \times 64$ channels, based on a combination of fluorescence and lightscatter signals. Regions of interest were analysis markers used to define a particular group of cells, typically the controls, for later estimation of shifts because of exposure to copper.

Changes in cell size (LS1), shape (LS2) and chlorophyll $a$ fluorescence were measured after 3- to 72-h exposure of cells to copper. In addition, cell esterase activity and membrane potential were determined on two separate subsamples from each toxicant concentration. The flow cytometer was operated using a constant flow rate of $20 \mu \mathrm{l} / \mathrm{min}$ and a pressure setting of 0.7 bar. Samples were accumulated for a preset time of $130 \mathrm{~s}$.

\section{Cell counts}

The Bio-Rad Bryte flow cytometer is unique in that cells are counted directly as the area under the curve from a plot of cell number versus chlorophyll $a$ fluorescence without the need for internal calibration with beads. Preliminary experiments comparing the flow cytometer counts with direct counts using phase-contrast microscopy and a hemocytometer or Coulter counter (Coulter Multisizer IIE Particle Analyzer with a $70-\mu \mathrm{m}$ aperture) were performed. For each species, a series of cell dilutions was prepared and counted using the three techniques. A range of flow rates $(3.0-50 \mu 1 / \mathrm{min})$ and pressure settings (0.4-1.2 bar) on the flow cytometer were tested for all species to optimize the cell count and algal distribution obtained.

The algal cell density was determined daily during the 72 $h$ copper exposure. Linear regression analysis was used to fit $\log _{10}$ cell density versus time (h) for each sample. The growth (i.e., cell division) rate was determined from the regression slope and expressed in terms of doublings/d.

\section{FDA fluorescence (esterase activity)}

Fluorescein diacetate is a nonfluorescent, lipophilic molecule that is readily taken up by algal cells and is cleaved by nonspecific esterases inside viable cells to produce fluorescent fluorescein, which is detected on the flow cytometer in the green spectrum (FL1). The FDA-stained cells fluoresce at a higher intensity than the unstained or heat-treated cells $\left(100^{\circ} \mathrm{C}\right.$ for $10 \mathrm{~min}$ ), in which esterases are inactivated. Inhibition of FDA fluorescence is an indicator of toxicant effects on either the cell membrane or the activity of esterases (i.e., enzymes involved in phospholipid turnover) in the cell. Inhibition of FDA fluorescence was determined both before and after exposure to copper for 1 to $24 \mathrm{~h}$.

Preliminary experiments were conducted to optimize the FDA concentration and incubation time for each algal species. An aliquot of a $1 \mathrm{mM}$ FDA stock solution (Sigma F-7378 in acetone, St. Louis, MO, USA) was added to a $5-\mathrm{ml}$ solution of cells to give a final concentration of $25 \mu \mathrm{M}$ FDA. Cells were incubated for 5 or $10 \mathrm{~min}$ before flow cytometric analysis. Negative controls (i.e., heat-treated cells and unstained cells) were included in each experiment together with acetone blanks.

Esterase activity was determined from a histogram of cell number versus log FL1 fluorescence. For each toxicant concentration, the percentage of cells falling into $S 1, S 2$, or $S 3$ (i.e., metabolic activity states) was compared with that of stained control cells. These regions were defined using reference histograms obtained by merging the fluorescence histograms of stained control and stained heat-treated samples 
(N.M. Franklin et al., unpublished data). The normal esterase activity state or S2 was defined around the distribution of healthy control cells (stained with FDA), whereas S1 and S3 defined the lower and higher esterase activity levels, respectively. Toxicity was expressed as a decrease in the number of cells in the $\mathrm{S} 2$ region as a percentage of controls.

To determine whether inhibition of FDA fluorescence was largely because of membrane disruption (i.e., reduced uptake of the dye) or inhibition of intracellular esterases, cells were also stained with the nucleic acid stain propidium iodide (PI). Propidium iodide only enters cells with damaged membranes and stains nucleic acids; thus, PI can be used to discriminate between live viable and nonviable (i.e., fluorescent) cells [9] Preliminary experiments were conducted to optimize the PI concentration and incubation time for each algal species. A stock solution of 100 or $1,000 \mu \mathrm{M}$ PI (Sigma P-4170 in Milli$\mathrm{Q}$ water) was added to $5-\mathrm{ml}$ aliquots of cells to give a final concentration of $7.5 \mu \mathrm{M}$ PI (5-min incubation) for the freshwater species Chlorella sp. and $S$. capricorntum and $60 \mu \mathrm{M}$ PI (5-min incubation) for the marine species $P$. tricornutum and $D$. tertiolecta. Negative controls (i.e., heat-treated cells and unstained cells) were included in each experiment. The orange fluorescent emission of this compound was collected in the FL2 channel (560-590 nm) after 1-, 3-, and 24-h exposures.

\section{Membrane potential}

The fluorescence of cells stained with 3,3'-dihexyloxacarbocyanine ( $\mathrm{DiOC}_{6}[3]$; Sigma) was measured to assess changes in the membrane potential of cells exposed to copper after 1 to $24 \mathrm{~h}$. The dye used is lipophilic, to permit passage through the cell membrane, and is positively charged. Once the cells are equilibrated with the dye, partitioning of the dye between the cells and the suspending medium is a function of the membrane potential. Hyperpolarization (i.e., an increase in membrane potential) occurs when the interior of the cell becomes more electrically negative with respect to the exterior, resulting in uptake of the dye. Depolarization (i.e., a decrease in membrane potential) occurs when the inside of the cell becomes less electrically negative with respect to the exterior, resulting in a release of the dye from the cell into the medium. The green fluorescence emitted by intracellular $\mathrm{DiOC}_{6}(3)$ was measured in FL1. Use of longer exposure times was not possible, because copper can cause an increase in cell size, resulting in increased $\mathrm{DiOC}_{6}(3)$ fluorescence per cell. This increase in green fluorescence can interfere with the interpretation of membrane potential effects. An aliquot of a $0.35 \mu \mathrm{M} \mathrm{DiOC}{ }_{6}(3)$ stock solution in acetone was added to a $5-\mathrm{ml}$ solution of copper-exposed cells to give a final concentration of $0.35 \mu \mathrm{M}$. The dye and cells were allowed to equilibrate for $5 \mathrm{~min}$ at room temperature before flow cytometric analysis. Three membrane potential states were defined, with $\mathrm{S} 2$ being set on healthy control cells and S1 and S3 indicating depolarization and hyperpolarization, respectively. Toxicity was expressed as a decrease in the number of cells in the $\mathbf{S} 2$ region as a percentage of controls.

\section{Statistical analysis}

Copper toxicity was expressed as an EC50 value (i.e., the concentration of copper that affected $50 \%$ of the cells). This effect could be an increase in cell size, an increase/decrease in chlorophyll $a$ fluorescence, or a decrease in esterase activity in $50 \%$ of the cell population. For growth, EC50 was the concentration of copper that caused a $50 \%$ reduction in the cell division rate compared with controls. The EC50 values were calculated using Trimmed Spearman-Karber analysis (ToxCalc Version 5.0.14, Tidepool Software, San Francisco, CA, USA). After testing the data for normality and homogeneity of variance, Dunnett's multiple-comparison test was used to determine which treatments differed significantly from the controls. The no-observable-effect concentration was the copper concentration at which no statistically significant effect was observed on the measured parameter compared with controls. The lowest-observable-effect concentration was the lowest concentration of copper to cause a statistically significant effect on the measured parameter compared with controls. Tests for significance between the sensitivity of different effect parameters (e.g., growth vs. chlorophyll $a$ fluorescence) were determined using a one-way analysis of variance or Student's $t$ test. Significance levels were tested at the $p=0.05$ level.

\section{RESULTS}

\section{Comparison of flow cytometry with other counting techniques}

Flow-cytometer counts from serial dilutions of each algal species were compared with microscopic and Coulter counts. A constant flow rate of $20 \mu 1 / \mathrm{min}$ and pressure setting of 0.7 bar were found to be optimal for each algal species. Good agreement was found between the microscopic and flow-cytometer counts (FL3) and between the Coulter and flow-cytometer counts (FL3). Slopes ranged from 0.98 to 1.13 , with $r^{2}$ values greater than 0.97 .

\section{Cell division rate inhibition}

Copper had an inhibitory effect on the cell division rate of each algal species after a 48- and 72-h exposure (Fig. 1). For the freshwater algae Chlorella $\mathrm{sp}$. and $S$. capricornutum, growth rates of $1.7 \pm 0.2$ doublings/d were obtained in the absence of copper, with a coefficient of variation of 2 to $5 \%$, indicating test acceptability. As the copper concentration in the medium increased, the cell division rate decreased, with complete inhibition at $30 \mu \mathrm{g} \mathrm{Cu} / \mathrm{L}$ (Fig. 1). The 72-h EC50 value for both species was $8 \pm 2 \mu \mathrm{g} / \mathrm{L}$. Shorter exposure times did not significantly $(p>0.05)$ alter copper toxicity, with a 48-h EC50 value of $6 \pm 2 \mu \mathrm{g} / \mathrm{L}$ (Table 2).

The cell division rate of $P$. tricornutum also decreased with increasing copper concentrations (Fig. 1). Maximum growth rates of $1.4 \pm 0.1$ and $1.5 \pm 0.1$ doublings/d were found in controls after 48 and $72 \mathrm{~h}$, respectively. Complete growth inhibition was observed at $750 \mu \mathrm{g} \mathrm{Cu} / \mathrm{L}$. The 48- and 72-h EC50 values were $9 \pm 3$ and $10 \pm 4 \mu \mathrm{g} \mathrm{Cu} / \mathrm{L}$, respectively (Table 2).

The D. tertiolecta growth was relatively insensitive to copper compared with that of the other test species. Maximum cell division rates in controls were $1.3 \pm 0.1$ doublings/day after 48- and 72-h copper exposures. Even at the highest copper concentration tested $(980 \mu \mathrm{g} / \mathrm{L})$, growth was observed. However, at this concentration, the solubility of copper in seawater may be exceeded, making the calculation of EC50 values of little relevance.

For each toxicity test, the $\mathrm{pH}$ drift was less than $0.5 \mathrm{pH}$ unit over $48 \mathrm{~h}$; however, an increase of as much as $1 \mathrm{pH}$ unit was sometimes observed in the controls by $72 \mathrm{~h}$ as a result of high final algal cell densities. This $\mathrm{pH}$ increase was within test-acceptability limits. 

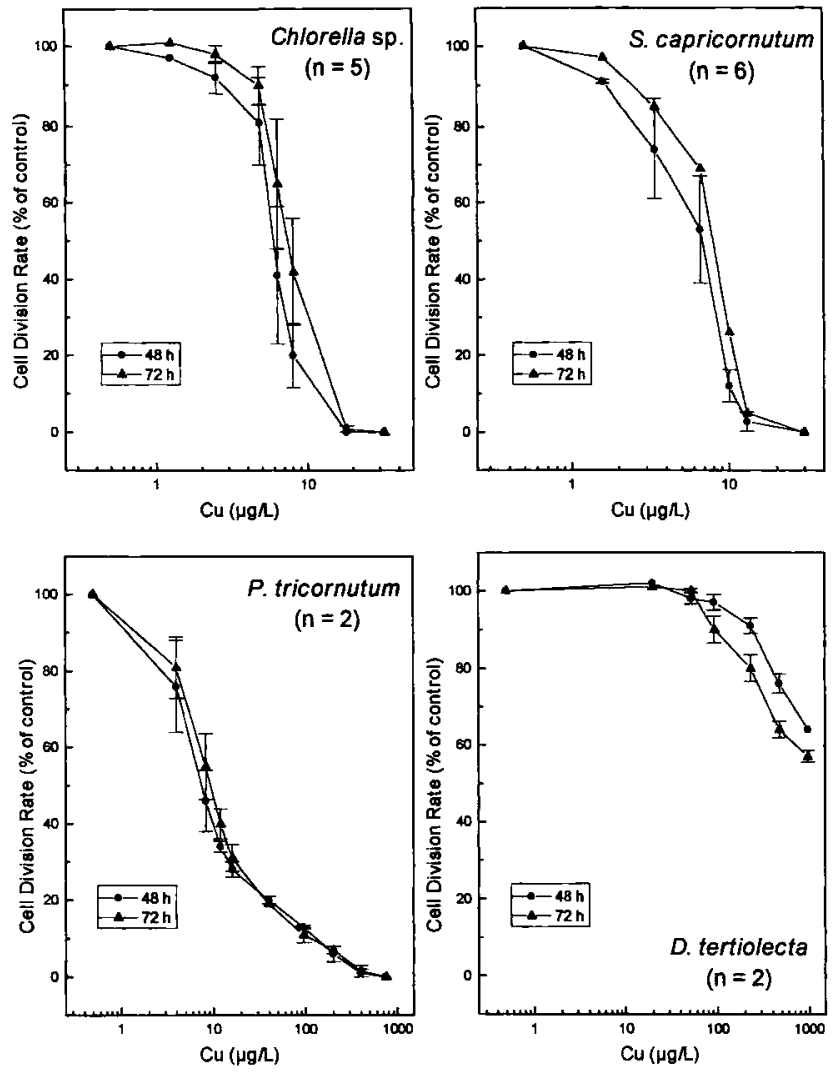

Fig. 1. Growth rate inhibition of Chlorella sp., Selenastrum capricornutum, Phaeodactylum tricornutum, and Dunaliella tertiolecta exposed to copper for 48 and $72 \mathrm{~h}$. Data points represent the mean \pm standard error of mean.

\section{Cell size/granularity}

Changes in cell size, as indicated by shifts in LS1, are illustrated for Chlorella sp. after a 48-h exposure to copper (Fig. 2). An increase in cell size is shown as a displacement of the LS1 histogram along the $x$-axis to the right. For this
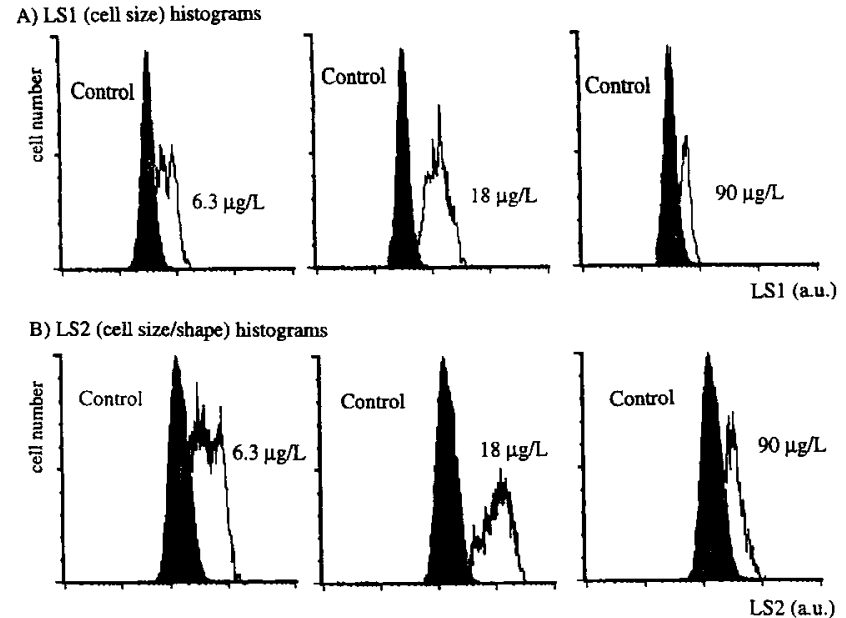

C) LS1 versus LS2 cytogram

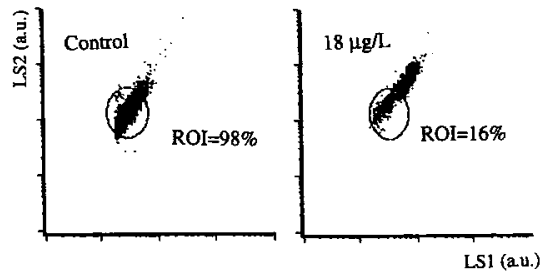

Fig. 2. Shifts in forward-angle light scatter (LS1, cell size; $\mathbf{A}$ ), sideangle light scatter (LS2, cell size/shape; B), and LS1 vs. LS2 cytogram for Chlorella sp. (C) without copper and with $6.3,18$, and $90 \mu \mathrm{g} \mathrm{Cu}$ / $\mathrm{L}$ after a 48 - $\mathrm{h}$ exposure. a.u. $=$ arbitrary units, $\mathrm{ROI}=$ region of interest.

alga, a maximum increase in cell size was observed at $18 \mu \mathrm{g}$ $\mathrm{Cu} / \mathrm{L}$, with $83 \%$ of cells being larger than controls. At higher copper concentrations (e.g., $90 \mu \mathrm{g} \mathrm{Cu} / \mathrm{L}$ ), only $35 \%$ of cells were enlarged. The effect of exposure time on cell size changes is shown in Figure 3. Cell size was not significantly $(p>0.05)$ altered after a 4-h exposure to copper concentrations of $90 \mu \mathrm{g} /$ L. Cells were significantly $(p \leq 0.05)$ larger relative to the control treatments in all copper treatments of $4 \mu \mathrm{g} / \mathrm{L}$ or greater

Table 2. Effect of copper on various parameters in marine and freshwater algae using flow cytometry

\begin{tabular}{|c|c|c|c|c|c|}
\hline \multirow[b]{3}{*}{ Effect parameter } & \multirow{3}{*}{$\begin{array}{l}\text { Exposure } \\
\text { duration (h) }\end{array}$} & \multicolumn{4}{|c|}{ EC50 $(\mu \mathrm{g} / \mathrm{L})$} \\
\hline & & \multicolumn{2}{|c|}{ Freshwater } & \multicolumn{2}{|c|}{ Marine } \\
\hline & & Chorella sp. ${ }^{\mathrm{a}}$ & S. capricornutum ${ }^{\mathrm{b}}$ & P. tricornutum $^{\mathrm{c}}$ & D. tertiolecta \\
\hline \multirow[t]{2}{*}{ Cell division rate } & 48 & $6 \pm 2$ & $6 \pm 2$ & $9 \pm 3$ & $1461 \pm 200^{\circ}$ \\
\hline & 72 & $8 \pm 2$ & $8 \pm 2$ & $10 \pm 4$ & $995 \pm 40^{i}$ \\
\hline \multirow{2}{*}{ Cell size $(\mathrm{LS} 1)^{\mathrm{d}}$} & 48 & $8 \pm 2$ & $>70$ & $8 \pm 3$ & $>980^{\mathrm{i}}$ \\
\hline & 72 & $13 \pm 4$ & $>70$ & $8 \pm 3$ & $>980$ \\
\hline \multirow[t]{2}{*}{ LS1 versus LS2 (cell size/shape) } & 48 & $8 \pm 2^{8}$ & $>70$ & $12 \pm 1$ & $>980$ \\
\hline & 72 & - h & $>70$ & $12 \pm 2$ & $>980$ \\
\hline \multirow{2}{*}{$\begin{array}{l}\text { Chlorophyll } a \text { fluorescence } \\
\text { (increase/stimulation) }^{\mathrm{r}}\end{array}$} & 48 & - & - & $9 \pm 3$ & $>980$ \\
\hline & 72 & - & - & $10 \pm 1$ & $>980$ \\
\hline \multirow{2}{*}{$\begin{array}{l}\text { Chlorophyll } a \text { fluorescence } \\
\text { (decrease/inhibition) }\end{array}$} & 48 & $73 \pm 45$ & $14 \pm 6$ & - & $>980$ \\
\hline & 72 & $40 \pm 5.0$ & $13 \pm 5$ & - & $>980$ \\
\hline
\end{tabular}

a $n=5$ tests for all parameters except for chlorophyll $a$ fluorescence measurements using LS1 threshold where $(n=2)$.

${ }^{\mathrm{b}} n=6$ tests for all parameters except for chlorophyll $a$ fluorescence measurements using LSI threshold where $(n=2)$

${ }^{\circ} n=2$ tests for all parameters.

${ }^{d} \mathrm{LS1}=$ forward angle light scatter.

${ }^{\mathrm{c}} \mathrm{LS} 2=$ side angle light scatter.

${ }^{\mathrm{f}}$ Threshold set on LS1 to see shifts in both directions in FL3.

g Endpoint derived from two tests only. Less than $50 \%$ shift was observed in a third test.

"Inconsistent shifts. Less than 50\% shift usually observed.

i Solubility of $\mathrm{Cu}$ may be exceeded, although no precipitation observed. 


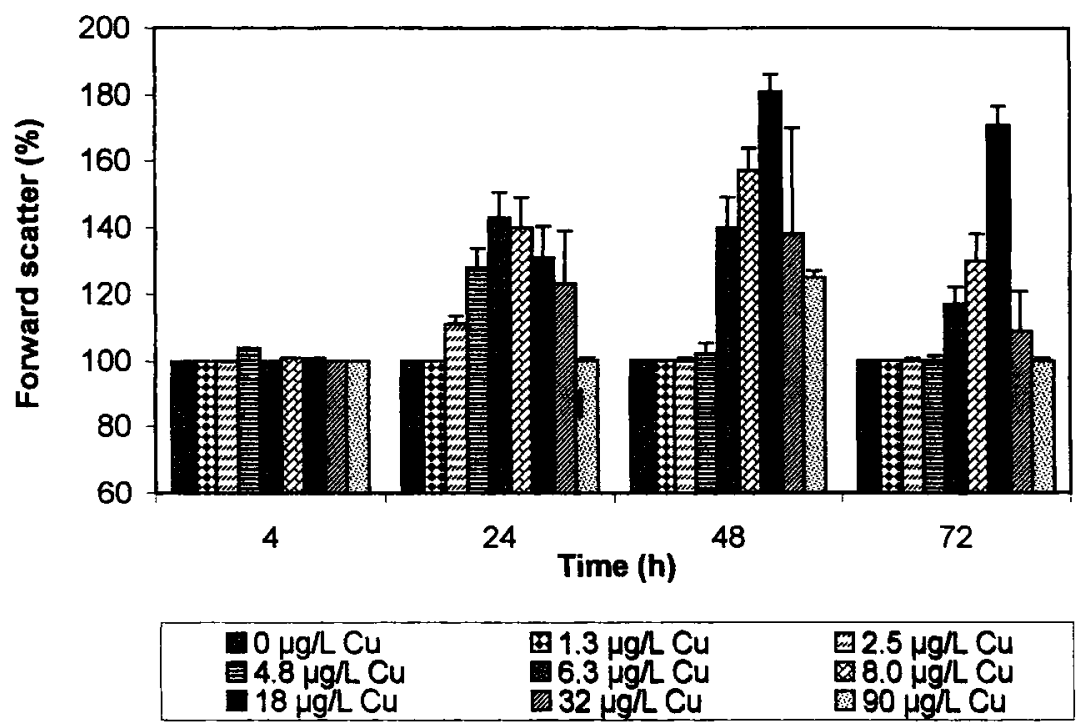

Fig. 3. Forward scatter (LS1) after 4-, 24-, 48-, and 72-h copper exposures of Chlorella sp. cells. Data are expressed as the percentage increase in cell size compared with control cells $(100 \%)$. Results are the mean \pm standard deviation of five tests.

(lowest-observable-effect concentration value) after a $24-\mathrm{h}$ copper exposure, with the exception of the $90-\mu \mathrm{g} / \mathrm{L}$ treatment. Maximum shifts in cell size were observed after 48-h copper exposure, with an EC50 value of $8 \pm 2 \mu \mathrm{g} \mathrm{Cu} / \mathrm{L}$ (Table 2). This EC50 value was similar to that for the cell division rate in this species $(6 \pm 2 \mu \mathrm{g} \mathrm{Cu} / \mathrm{L})$. After a $72-\mathrm{h}$ exposure, cells had shifted back toward the control region, with an EC50 value of $13 \pm 4 \mu \mathrm{g} / \mathrm{L}$ (Table 2 ).

Side-angle light scatter (LS2) showed the same pattern as LS1 for Chlorella sp., with maximum increases after $48 \mathrm{~h}$ at $18 \mu \mathrm{g} / \mathrm{L}$. These shifts are readily seen on the cytogram plot (LS1 vs. LS2) shown in Figure 2. In the absence of copper, $98 \%$ of cells were detected in the region of interest, whereas in the $18-\mu \mathrm{g} / \mathrm{L}$ treatment, most cells had increased light scatter in both directions, with only $16 \%$ remaining in the control region. The 48-h EC50 value calculated from the cytogram using LS1 and LS2 was the same as the LS1 EC50 value calculated from the histogram $(8 \pm 2 \mu \mathrm{g} / \mathrm{L}$ ) (Table 2 ). Inconsistent shifts were found after a 72 -h exposure. Toxicity endpoints based on cytogram measurements of LS1-LS2 were less consistent between tests than toxicity based on LS1 or LS2 measurements alone. This may have resulted from the subjective way in which the region of interest was set on each cytogram, a technique that was improved substantially when using histograms by standardizing the region-of-interest settings to include $95 \%$ of cells, with the lower limit being positioned in the first empty channel to the left of the control distribution.

Copper also caused a concentration-dependant increase in the size of $S$. capricornutum cells relative to the controls after 24-, 48-, and 72-h exposures. Maximum shifts in cell size were observed at $30 \mu \mathrm{g} \mathrm{Cu} / \mathrm{L}$, with as much as 20,40 , and $45 \%$ of cells being enlarged compared with control cells after 24-, 48-, and 72-h copper exposures, respectively. A $50 \%$ effect was not observed; therefore, EC50 values based on LS1 (i.e., cell size) or LS2 (i.e., cell size/shape) were greater than the highest copper concentration tested (Table 2).

Similar to the effect in other species, copper caused an increase in cell size of $P$. tricornutum after 24-, 48-, and 72$\mathrm{h}$ exposures. After $24 \mathrm{~h}$, cell size increased with increasing copper concentration, with $50 \%$ or more of the cells being larger than controls at $200 \mu \mathrm{g} / \mathrm{L}$. Similar increases in cell size were observed at $10 \mu \mathrm{g} \mathrm{Cu} / \mathrm{L}$ after 48 and $72 \mathrm{~h}$, with an EC50 value of $8 \pm 3 \mu \mathrm{g} / \mathrm{L}$ (Table 2). Similar changes in cell size/ shape were also reflected in changes in side-angle light scatter (LS2) (Table 2).

For D. tertiolecta, no significant changes in cell size/granularity were detected at copper concentrations less than the solubility level of copper in seawater $(\sim 500 \mu \mathrm{g} / \mathrm{L})$.

\section{Chlorophyll a fluorescence}

Copper caused both an increase and a decrease in chlorophyll $a$ fluorescence of Chlorella sp., S. capricornutum, and $P$. tricornutum, depending on the period of exposure and copper concentration (Fig. 4). For Chlorella sp., changes in chlorophyll $a$ fluorescence were not observed after a 4-h exposure to copper at concentrations up to $450 \mu \mathrm{g} / \mathrm{L}$. After $24 \mathrm{~h}$, low copper concentrations $(<10 \mu \mathrm{g} / \mathrm{L})$ caused a small increase $(<20 \%)$ in chlorophyll $a$ fluorescence, whereas concentrations of $90 \mu \mathrm{g} \mathrm{Cu} / \mathrm{L}$ or greater caused a decrease in fluorescence. These changes were more pronounced after a 48 -h exposure (Fig. 4). Increasing copper concentrations resulted in increasing inhibition of chlorophyll $a$ fluorescence, which was seen as a shift to the left of the control region. The 48-h EC50 value was $73 \pm 45 \mu \mathrm{g} / \mathrm{L}$ (i.e., at $73 \mu \mathrm{g} \mathrm{Cu} / \mathrm{L}$, approximately $50 \%$ of the cells were fluorescing at a lower intensity than the controls). Shifts in chlorophyll $a$ fluorescence showed a similar pattern after a 72-h exposure to copper, with a 72-h EC50 value of $40 \pm 5 \mu \mathrm{g} / \mathrm{L}$.

For $S$. capricornutum, significant inhibition of chlorophyll $a$ fluorescence was found after 24-, 48-, and 72-h exposures to copper concentrations of $1.6 \mu \mathrm{g} / \mathrm{L}$ or greater. Chlorophyll $a$ fluorescence decreased compared with controls as the copper concentration increased (Fig. 4). More than $90 \%$ of cells had reduced fluorescence compared with controls at $70 \mu \mathrm{g} / \mathrm{L}$ after 48 and $72 \mathrm{~h}$. The 48- and 72-h EC50 values based on inhibition of chlorophyll $a$ fluorescence were $14 \pm 6$ and $13 \pm 5 \mu \mathrm{g} / \mathrm{L}$, respectively (Table 2 ). Small increases in chlorophyll $a$ fluorescence were also observed over 24 to $72 \mathrm{~h}$; however, these were less than $20 \%$ of control cells.

Chlorophyll $a$ fluorescence was found to both increase and decrease in $P$. tricornutum cells after 24-, 48-, and 72-h copper 

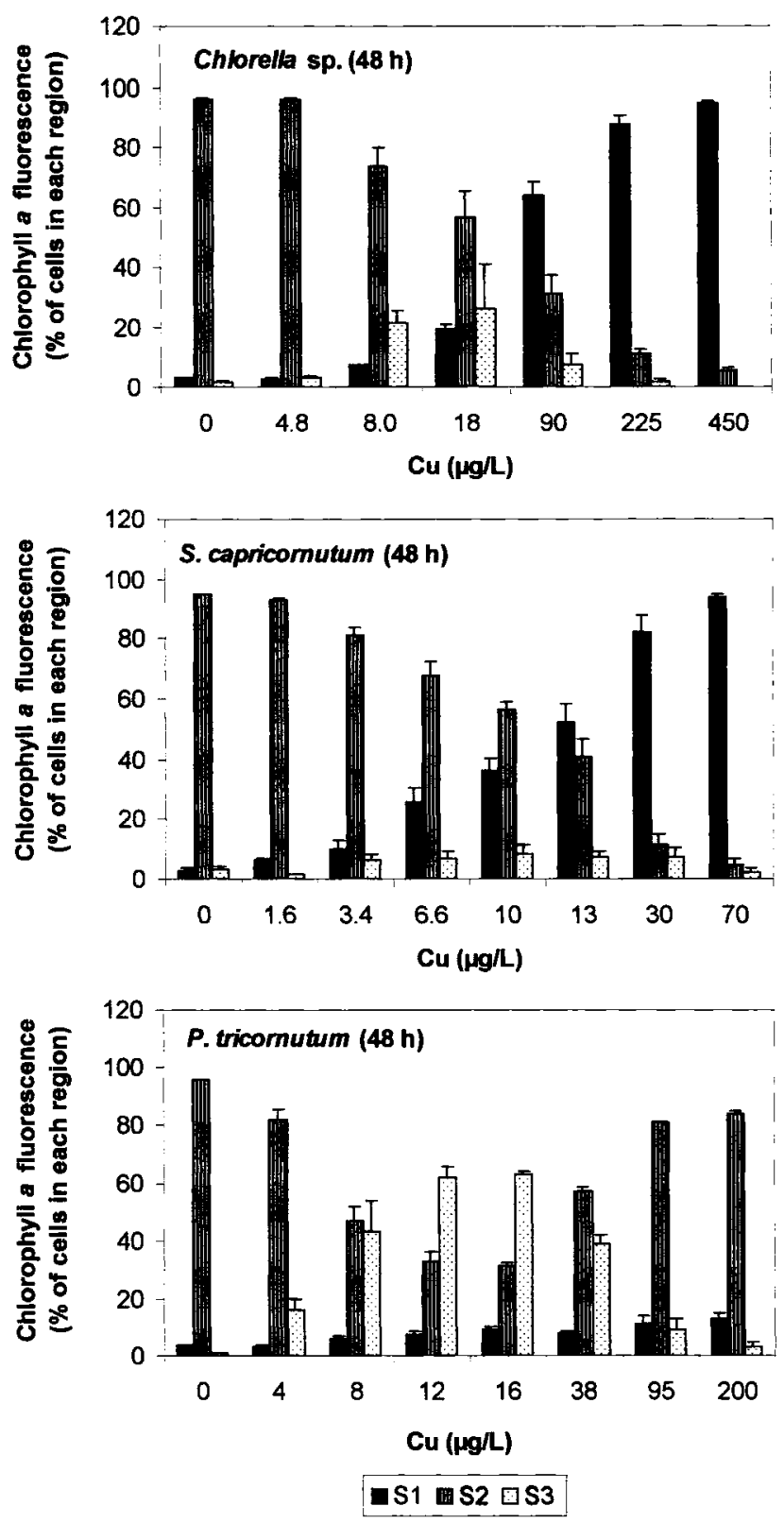

Fig. 4. Shifts in chlorophyll $a$ fluorescence of Chlorella sp., Selenastrum capricornutum and Phaeodactylum tricornutum after a 48-h $\mathrm{Cu}$ exposure. Data points represent the mean \pm standard error of mean of two to six tests. S1 = decreased fluorescence intensity, $\mathbf{S 2}=$ chlorophyll $a$ fluorescence of control cells, S3 = increased fluorescence intensity.

exposures (Fig. 4). Shifts in fluorescence (both increases and decreases) were less than $20 \%$ at copper concentrations up to $200 \mu \mathrm{g} / \mathrm{L}$ after $24 \mathrm{~h}$. Longer exposure periods (48 and $72 \mathrm{~h}$ ) resulted in pronounced increases in chlorophyll $a$ fluorescence, with $60 \%$ of cells fluorescing at a higher intensity at $11 \mu \mathrm{g}$ $\mathrm{Cu} / \mathrm{L}$ (Fig. 4). The 48- and 72-h EC50 values based on stimulation of chlorophyll $a$ fluorescence were $9 \pm 3$ and $10 \pm 1$ $\mu \mathrm{g} / \mathrm{L}$, respectively (Table 2 ).

No significant changes in chlorophyll $a$ fluorescence were observed for $D$. tertiolecta at copper concentrations up to 500 $\mu \mathrm{g} / \mathrm{L}$.

\section{FDA fluorescence (esterase activity)}

The suitability of esterase activity as an acute toxicity test endpoint was assessed over 1 - to $24-\mathrm{h}$ exposures to copper.

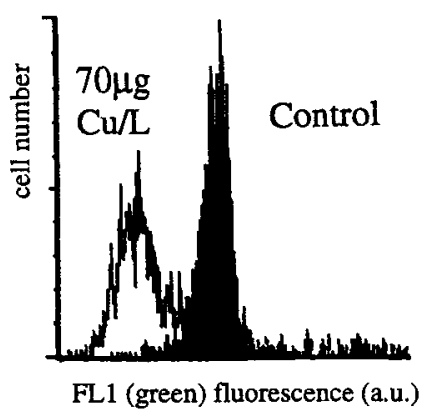

Fig. 5. Histogram overlay showing shift in esterase activity in Selen astrum capricornutum cells without $\mathrm{Cu}(\bullet)$ and with $70 \mu \mathrm{g} \mathrm{Cu} / \mathrm{L}(\mathrm{O})$ after a 48-h exposure. a.u. = arbitrary units.

Preliminary experiments to optimize FDA bioassay conditions, including FDA substrate concentration and incubation period, are not reproduced here (N.M. Franklin et al., unpublished data). For Chlorella sp., at copper concentrations up to $90 \mu \mathrm{g} /$ $\mathrm{L}$, no effects on cell esterase activity were observed after either a 1- or 4-h exposure using $25 \mu \mathrm{M}$ FDA and a 10-min incubation time. Significant inhibition of esterase activity (25$40 \%$ ) was detectable after a 24-h exposure to copper concentrations of $90 \mu \mathrm{g} / \mathrm{L}$ or greater. A $50 \%$ effect (i.e., $50 \%$ of cells shifted into S1) was only observed at $450 \mu \mathrm{g} \mathrm{Cu} / \mathrm{L}$. At this concentration, the solubility of copper in freshwater may have been exceeded, although no precipitation was observed. Propidium iodide staining of these cells showed that copper concentrations up to $450 \mu \mathrm{g} / \mathrm{L}$ did not significantly alter cell mem brane integrity after a $24-\mathrm{h}$ exposure. Less than $2 \%$ of cells in the controls and copper treatments $(\leq 450 \mu \mathrm{g} \mathrm{Cu} / \mathrm{L})$ were nonviable.

Cell esterase activity was measured for $S$. capricornutum after 1-, 3-, and 24-h copper exposures ( $25 \mu \mathrm{M}$ FDA, $5 \mathrm{~min}$ ). A decrease in esterase activity was detected as a shift in the FL1 histogram to the left of the control region (i.e., a shift into S1) (Fig. 5). Esterase activity decreased as the copper concentration in the medium increased (Fig. 6). Maximum inhibition of esterase activity was found at $175 \mu \mathrm{g} \mathrm{Cu} / \mathrm{L}$ for all exposure times, with a $70 \%$ shift of cells into the lower esterase activity state (S1).

Minor increases in esterase activity were found after 1 - and 3-h exposures yet were typically less than $10 \%$ of control cells. The 1- and 3-h EC50 values (i.e., the copper concentration at which $50 \%$ of cells have lower esterase activity compared with controls) were $114 \pm 49$ and $90 \pm 42 \mu \mathrm{g} / \mathrm{L}$, respectively.

After a $24-\mathrm{h}$ copper exposure, substantial increases and decreases in esterase activity were observed for $S$. capricornutum. Esterase activity increased compared with the control treatment at the lower copper concentrations tested (3.4-30 $\mu \mathrm{g} / \mathrm{L}$ ), whereas higher copper concentrations ( $\geq 30-175 \mu \mathrm{g} /$ L) caused a decrease in esterase activity (Fig. 6). The maximum increase in esterase activity was $75 \%$ at $3.4 \mu \mathrm{g} / \mathrm{L}$. The 24-h EC50 value based on inhibition of esterase activity was $39 \pm 18 \mu \mathrm{g} / \mathrm{L}$.

The percentage of nonviable cells of $S$. capricornutum, as measured using PI staining, did not show significant variations from that of controls cultures ( $<5 \%$ nonviable cells) at copper concentrations up to $175 \mu \mathrm{g} \mathrm{Cu} / \mathrm{L}$ after 1 - to $24-\mathrm{h}$ exposures.

The effect of copper on cell esterase activity using FDA could not be measured for $P$. tricornutum. Despite a series of optimization experiments for this species, insufficient uptake and hydrolysis of FDA were found under standard bioassay 

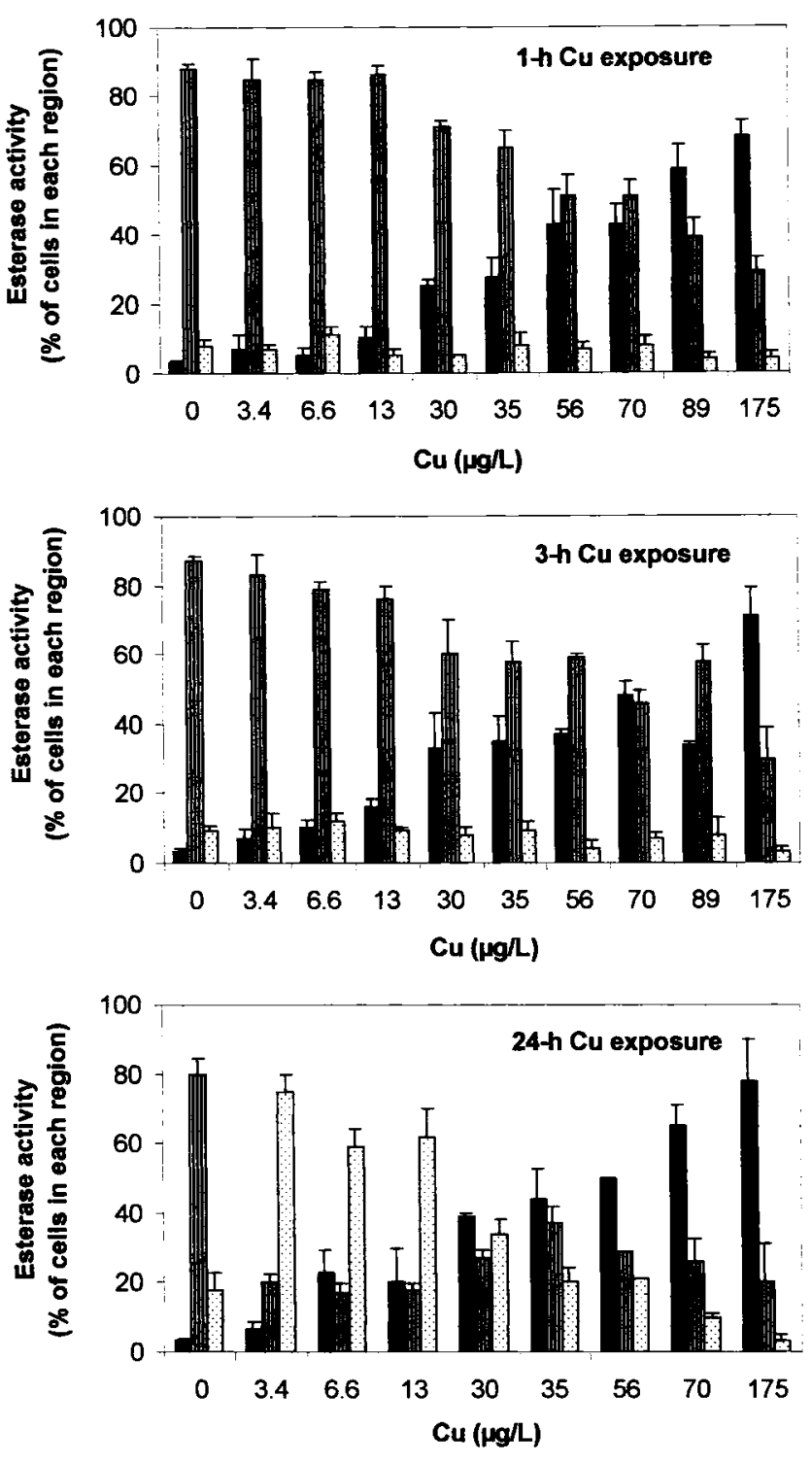

\section{DS1 1 S2 $\boxminus \mathrm{S} 3$}

Fig. 6. Shifts in esterase activity of Selenastrum capricornutum cells after 1-, 3-, and 24-h Cu exposures. Data points represent the mean \pm standard error of mean of two to six tests. $S 1=$ a decrease in esterase activity, $\$ 2=$ esterase activity in control cells, $\$ 3=$ an increase in esterase activity.

conditions ( $\mathrm{pH} 7.5-8.0$, FDA concentrations of $0.1-100 \mu \mathrm{M}$; N.M. Franklin et al., unpublished data). The percentage of nonviable cells of $P$. tricornutum, as measured using PI staining, did not show significant variations from that of control cultures ( $<5 \%$ nonviable cells) at copper concentrations up to $200 \mu \mathrm{g} \mathrm{Cu} / \mathrm{L}$ after 1 - to 24 -h exposures.

Effects on esterase activity were also measured after 3- or 24-h copper exposures for $D$. tertiolecta (final FDA concentration of $25 \mu \mathrm{M}$; incubation time of $5 \mathrm{~min}$ ). At copper concentrations up to $470 \mu \mathrm{g} / \mathrm{L}$, no change in esterase activity was observed after 3- or 24-h exposures.

Similarly, PI staining of $D$. tertiolecta cells showed that high concentrations of copper did not significantly alter cell membrane integrity over a 24 -h copper exposure, with the percentage of nonviable cells being less than $2 \%$ in both control cultures and copper treatments.

\section{Membrane potential}

The effect of copper on cell membrane potential was measured after 1-, 4-, and 24-h exposures using $\mathrm{DiOC}_{6}(3)$. For Chlorella sp. and $S$. capricornutum, short exposures to copper ( 1 or $4 \mathrm{~h}$ ) had no effect on membrane potential at copper concentrations up to $450 \mu \mathrm{g} / \mathrm{L}$. However, after a $24-\mathrm{h}$ exposure, cells showed significant increases in FL1 green fluorescence, ranging from 12 to $30 \%$. This may be caused by hyperpolarization or increased cell size, with a consequent increase in fluorescence per cell.

For $P$. tricornutum, no differences in membrane potential were found after a 1-h exposure at $200 \mu \mathrm{g} \mathrm{Cu} / \mathrm{L}$, but after 4 h, 20 to $60 \%$ of cells treated with 38 to $400 \mu \mathrm{g} \mathrm{Cu} / \mathrm{L}$ showed decreased membrane potential (i.e., depolarization). Further depolarization was observed after a 24-h copper exposure, with $75 \%$ of cells being in the S1 state.

The effect of copper on the membrane potential of $D$. tertiolecta cells was measured after a 3- and 24-h exposure using $\mathrm{DiOC}_{6}(3)$. No changes in membrane potential were detectable.

\section{DISCUSSION}

This study applied a new ecotoxicological tool, flow cytometry, to investigate the responses of marine and freshwater phytoplankton to copper. Through the ability of flow cytometry to threshold on chlorophyll $a$ fluorescence, dead cells could easily be distinguished from live cells, so that only viable cells were included in cell counts used to determine inhibition of the cell division rate. In addition, flow cytometry enabled simultaneous determination of other ecologically relevant, sublethal endpoints, including chlorophyll $a$ fluorescence, cell size (i.e., light scattering), and enzyme activity. These parameters not only provide further evidence regarding the mechanism of copper toxicity to microalgae but may also be useful as alternative endpoints in acute and chronic toxicity tests.

\section{Mechanisms of toxicity of copper}

Light-scattering and fluorescent properties of algal cells, as detected by flow cytometry, provide additional information regarding the toxic mode of action of copper, which differs between species. In $S$. capricornutum, the first observable physiological change in response to copper was a decrease in FDA fluorescence, indicating changes in either cell membrane permeability and/or esterase activity within the cells. Lack of PI uptake suggested that the decreased FDA fluorescence resulted from inhibition of intracellular esterases. After $24 \mathrm{~h}$, changes in cell size and membrane potential were clearly evident, with possible hyperpolarization of cells in the freshwater species $S$. capricornutum and Chlorella sp. and depolarization in the marine diatom $P$. tricornutum. Cid et al. [9] also reported that copper caused a progressive loss in membrane integrity in $P$. tricornutum, followed by alterations in cell membrane potential, and an increase in intracellular $\mathrm{pH}$. Changes in chlorophyll $a$ fiuorescence were also observed at this time, with a reduction in fluorescence for the two freshwater species and an increase in fluorescence for $P$. tricornutum. For all species, alterations in chlorophyll $a$ fluorescence were paralleled by changes in light scattering, indicating an increase in cell size. Increases in cell size may result from increased cell permeability to $\mathrm{Na}^{+}$, as found in $D$. marina [23], or from an uncoupling of cell division and photosynthesis, as found in Nitzschia closterium [24]. Cells continue to fix carbon but cannot divide, leading to enlarged cells as photosynthetic products 
accumulate. After 48- and 72-h exposures, both the cell division rate and chlorophyll $a$ fluorescence were severely inhibited; therefore, cell swelling was reduced and lethal effects observed at high copper concentrations.

In contrast to the other species tested, D. tertiolecta was tolerant to copper, even at concentrations up to the solubility limit of copper in seawater. Neither the cell division rate, chlorophyll $a$ fluorescence, esterase activity, cell size, nor cell membrane changes were detectable. Abalde et al. [12] also found that copper concentrations up to $8 \mathrm{mg} / \mathrm{L}$ had no effect on the growth of $D$. tertiolecta, although high cell densities and copper concentrations exceeding the copper solubility in seawater were used. Similar tolerance of the genus Dunaliella has been shown for a range of heavy metals [25]. This tolerance may result from the exclusion of copper from the cell through binding to exudates extracellularly, as found in other species [26], or from intracellular detoxification by binding to phytochelatins or polyphosphate granules [27].

\section{Toxicity test endpoints}

Cell division rate inhibition. Several parameters measured by flow cytometry were suitable as chronic toxicity test endpoints. With the exception of that involving $D$. tertiolecta, chronic tests based on cell division inhibition were both sensitive and reproducible, with EC50 values after 48- and 72-h copper exposures of $10 \mu \mathrm{g} \mathrm{Cu} / \mathrm{L}$ or less. Under comparable bioassay conditions, similar sensitivity of cell division rate inhibition to copper has been reported for another freshwater Chlorella species [28], for S. capricornutum [29], and for the marine diatom $N$. closterium [24] using a Coulter particle counter for cell counting. For the marine diatom $P$. tricornutum, the 48-h EC50 value obtained in this study $(9 \pm 3 \mu \mathrm{g} /$ L) was much lower than the $48-\mathrm{h} \mathrm{EC50}$ of $208 \mu \mathrm{g} / \mathrm{L}$ reported by Cid et al. [9] for the same species using flow cytometry. Those authors, however, used a much higher initial cell density $\left(10^{5}\right.$ cells $\left./ \mathrm{ml}\right)$, which has been shown to reduce metal toxicity [24].

Cell size/granularity. The light-scattering properties of two algal species, Chlorella sp. and $P$. tricornutum, were useful as alternative chronic test endpoints. Copper caused an increase in cell size, as indicated by forward-angle light scatter (i.e., LS1), that depended on the concentration and duration of exposure to copper and the test species. This increase in cell size was confirmed by direct observation of the cells using phase-contrast microscopy. The change in cell size after 1 - to 4-h copper exposures was not a sensitive endpoint compared with cell division rate inhibition over 48 to $72 \mathrm{~h}$. However, at longer exposure periods ( 48 and $72 \mathrm{~h}$ ), increases in cell size were of similar sensitivity and reproducibility as the cell division rate inhibition (Table 2). Cid et al. [9] also found that the LS1 of $P$. tricornutum increased after a $96-\mathrm{h}$ exposure to $500 \mu \mathrm{g} \mathrm{Cu} / \mathrm{L}$.

Similar increases in side-angle light scatter (i.e., LS2), related to internal cell complexity/granularity, were also found to be a useful indicator of chronic copper toxicity for Chlorella sp. and $P$. tricornutum. Ultrastructural changes in algae have been reported as a result of copper exposure, and these changes may possibly contribute to the increase in LS2 that is detectable by flow cytometry. Reiriz et al. [11] detected a gradual increase in the LS2 of $P$. tricornutum over $72 \mathrm{~h}$ as the copper concentration increased up to $28 \mathrm{mg} / \mathrm{L}$. The authors related this increase to ultrastructural changes, mainly in lysosomes and vacuoles, as detected by electron-microscopy techniques ( $\mathrm{S}$.
Reiriz et al., unpublished data). Rachlin et al. [30] reported the appearance of electron-dense granular bodies in the bluegreen alga Plectonema boryanum in response to copper. The development of membranous organelles $[31,32]$ and increases in vacuole volume [21] have also been reported in a variety of microalgal species exposed to copper.

Chlorophyll a fuorescence. Chlorophyll $a$ fluorescence is a function of the cell pigment content and of the photochemical activity of Photosystem II (PS II) in the photosynthetic electron-transport chain [33]. When measuring fluorescence, two important fluorescence levels need to be defined. The first, $F_{0}$, is the minimum fluorescence yield and occurs when the PS II reaction centers remain open [34]. This fluorescence describes excitation losses that occur during the transfer of excitation from the pigment bed to the reaction center [33]. When the reaction centers are closed, fluorescence rises to a maximum that is referred to as $F_{\max }$ [33]. Chlorophyll $a$ fluorescence as measured by flow cytometry is reported to be intermediate between $F_{0}$ and $F_{\max }$ [34].

This study showed that chlorophyll $a$ fluorescence, as detectable by flow cytometry, was not a sensitive indicator of copper toxicity over short-term exposures. However, with chronic exposure $(>24 \mathrm{~h}$ ), fluorescence measurements provided a useful toxicity endpoint with a sensitivity comparable to that of cell division rate inhibition (Table 2). According to Samson et al. [35], inhibition of chlorophyll $a$ fluorescence, as shown in $S$. capricornutum and Chlorella sp. in our study, may result from the inhibition of electron flow in the PS II reaction center at the donor side. Alternatively, an increase in chlorophyll $a$ fluorescence was observed if the inhibition occurred on the acceptor side of PS II [35,36]. Cid et al. [13] reported similar increases in chlorophyll $a$ fluorescence of $P$. tricornutum as found in the present study; however, they used a much higher copper concentration of $1,000 \mu \mathrm{g} / \mathrm{L}$ in a $24-\mathrm{h}$ exposure.

FDA fluorescence (esterase activity). Whereas light-scattering and fluorescent properties of the algal cells provided useful toxicity test endpoints for chronic copper exposures, none were sensitive enough to detect acute effects in shortterm bioassays. Bentley-Mowat [37] first reported use of the fluorimetric stain FDA and fluorescence microscopy for detecting the viability of marine phytoplankton in pollution studies. Detection of fluorescein fluorescence by flow cytometry. rather than by fluorescence microscopy, has recently been applied to assess the toxicity of heavy metals $[11,19,38]$ as well as pesticides and herbicides [39] to a variety of marine and freshwater phytoplankton. Fluorescein fluorescence (the endpoint measured) reflects esterase activity and cell membrane integrity [40], both of which indicate cell viability [14].

Flow cytometric detection of cell esterase activity using FDA was assessed for its potential as a rapid acute toxicity test using the four algal species. In $S$. capricornutum, fluorescein fluorescence was stimulated at low copper concentrations for exposures of $24 \mathrm{~h}$ or less. This probably resulted from increased uptake of FDA rather than increased esterase activity as a result of cell membrane hyperpolarization (i.e., net influx of dyes into the cell). At higher copper concentrations, fluorescein fluorescence was markedly reduced because of the uptake of copper into the cell and the inhibition of esterase activity. The EC50 as determined using this endpoint was less sensitive than the cell division rate over 48 to $72 \mathrm{~h}$, but the advantage of the FDA bioassay is that results can be obtained within $1 \mathrm{~h}$, providing a rapid means of acute toxicity assess- 
ment. Esterase activity in $S$. capricornutum was more sensitive to copper than the 5-h test for Tetraselmis suecica [39] but of comparable sensitivity to Microcystis aeruginosa after 24 h [38].

The FDA bioassay was not a useful endpoint in toxicity tests with Chlorella sp. or P. tricornutum. For Chlorella sp., esterase activity was relatively insensitive to copper, even at concentrations that severely inhibited the cell division rate. The marine diatom $P$. tricornutum was unique among the species tested, because minimal uptake and hydrolysis of FDA was found under standard bioassay conditions ( $\mathrm{pH} 7.5-8.0$ ). Altering substrate concentration and exposure time had no effect on FDA uptake and hydrolysis. This result is in agreement with that of Bentley-Mowat [37], who, using fluorescence microscopy to screen eight species of diatoms, also reported minimal production of fluorescent fluorescein from FDA in growing cultures of $P$. tricornutum.

\section{Comparison of toxicity endpoints}

This study confirmed that toxicity tests based on inhibition of the algal cell division rate over 48 to $72 \mathrm{~h}$ provide the most sensitive and reproducible chronic toxicity test endpoint. Stauber [29] also found that growth rate inhibition was the most sensitive endpoint to copper in toxicity tests with $N$. closterium. No significant effects of copper on photosynthesis (measured as $\left[{ }^{14} \mathrm{C}\right]$-uptake), ATP, or electron transport-chain activity were found at concentrations that substantially inhibited the algal cell division rate. In the present study, changes in algal cell size were equally sensitive for Chlorella sp. and $P$. tricornutum. Likewise, chlorophyll $a$ fluorescence bioassays show promise for routine testing with $S$. capricornutum and $P$. tricornutum. For acute toxicity over short exposure periods $(<24 \mathrm{~h})$, esterase activity in $S$. capricornutum may be a rapid alternative for monitoring copper toxicity in mineimpacted waters.

\section{CONCLUSIONS}

Flow cytometric techniques offer several advantages over conventional algal bioassay techniques, including speed of measurement, sensitivity, and ability to gather information simultaneously on the morphological, biochemical, and physiological effects of a toxicant. The results of this study show that flow cytometry can be used for routine toxicity testing with microalgae, both to accurately count viable cells in growth inhibition bioassays and to quantify alternative endpoints, such as changes in algal cell size, chlorophyll $a$ fluorescence, and enzyme activity. In particular, the in vivo esterase inhibition bioassay using $S$. capricornutum offers a rapid and reliable method for determining copper toxicity in copper-polluted waters. The appropriateness of different toxicity test endpoints can only be determined by understanding the mechanisms of toxicity of metals, which vary with different species and different exposure periods. Future research aims to use flow cytometry to develop more environmentally relevant toxicity tests using lower initial cell densities. Current bioassays use high cell densities ( $>10^{4}$ cells $\left./ \mathrm{ml}\right)$, which are generally higher than algal bloom cell numbers in natural waters. This is particularly important for metal bioavailability studies, in which the cells themselves can alter the speciation of metals in solution and, consequently, lead to over- or underestimation of metal bioavailability in natural waters. for help with the flow cytometry methodology and Monique Binet for technical assistance. This research was supported by an Australian Postgraduate Research Award.

\section{REFERENCES}

1. Environment Canada. 1992. Biological test method: Growth inhibition testing using the freshwater alga Selenastrum capricornutum. Report EPSI/RM/25. Ottawa, ON.

2. U.S. Environmental Protection Agency. 1994. Short-term methods for estimating the chronic toxicity of effluents and receiving waters to freshwater organisms, 3rd ed. EPA-600-4-91-002. Cincinnati, $\mathrm{OH}$

3. Cairns J, McCormick PV, Belanger SE. 1992. Ecotoxicological testing: Small is reliable. $J$ Environ Pathol Toxicol Oncol 11: 247-263.

4. Yentsch CM, et al. 1983. Flow cytometry and cell sorting: A powerful technique for analysis and sorting of aquatic particles Limnol Oceanogr 28:1275-1280.

5. Shapiro HM. 1995. Practical Flow Cytometry, 3rd ed. Wiley Liss, New York, NY, USA.

6. Faber MJ, Smith LMJ, Boermans HJ, Stephenson GR, Thompson DG, Solomon KR. 1997. Cryopreservation of fluorescent markerlabeled algae (Selenastrum capricornutum) for toxicity testing using flow cytometry. Environ Toxicol Chem 16:1059-1067.

7. Premazzi G, Buonaccorsi G, Zilio P. 1989. Flow cytometry for algal studies. Water Res 23:431-442.

8. Breeuwer P, Drocourt JL, Bunschoten N, Zwietering MH, Rombouts FM, Abee T. 1995. Characterisation of uptake and hydrolysis of fluorescein diacetate and carboxyfluorescein diacetate by intracellular esterases in Saccharomyces cerevisiae, which result in accumulation of fluorescent product. Appl Environ Microbiol 61:1614-1619.

9. Cid A, Fidalogo P, Herrero C, Abalde J. 1996. Toxic action of copper on the membrane system of a marine diatom measured by flow cytometry. Cytometry 25:32-36.

10. Müller S, Loffhagen N, Bley T, Babel W. 1996. Membrane-potential-related fluorescence intensity indicates bacterial injury. Microbiol Res 151:127-131.

11. Reiriz S, Cid C, Torres E, Abalde J, Herrero C. 1994. Different responses of the marine diatom Phaeodactylum tricornutum to copper toxicity. Microbiología 10:263-272.

12. Abalde J, Cid A, Reiriz S, Torres E. 1995. Response of the marine microalga Dunaliella tertiolecta (Chlorophyceae) to copper toxicity in short time experiments. Bull Environ Contam Toxicol 54: 317-324.

13. Cid A, Herrero C, Torres E, Abalde J. 1995. Copper toxicity on the marine microalga Phaeodactylum tricornutum: Effects on photosynthesis and related parameters. Aquat Toxicol 31:165174.

14. Blaise C, Ménard L. 1998. A micro-algal solid phase test to assess the toxic potential of freshwater sediments. Water Qual Res $J$ Can 33:133-151.

15. Sunda WG, Huntsman SA. 1983. Effect of competitive interactions between manganese and copper on cellular manganese and growth in estuarine and oceanic species of the diatom Thalassiosira. Limnol Oceanogr 28:924-934.

16. Stauber JL, Florence TM. 1987. Mechanism of toxicity of ionic copper and copper complexes to algae. Mar Biol 94:511-519.

17. Wong SL, Nakamoto L, Wainwright JF. 1994. Identification of toxic metals in affected algal cells in assays of wastewaters. $J$ Appl Phycol 6:405-414.

18. Peterson SM, Stauber JL. 1996. New algal enzyme bioassay for the rapid assessment of aquatic toxicity. Bull Environ Contam Toxicol 56:750-757.

19. Arsenault G, Cvetkovic AD, Popovic R. 1993. Toxic effects of copper on Selenastrum capricornutum measured by a flow cytometry-based method. Water Pollut Res J Can 28:757-765.

20. Florence TM, Stauber JL. 1986. Toxicity of copper complexes to the marine diatom Nitzschia closterium. Aquat Toxicol 8:11-26.

21. Thompson AS, Rhodes JC, Pettman I. 1988. Culture collection of algae and protozoa catalogue of strains. Natural Environmental Research Council, Swindon, UK.

22. Guillard RRL, Ryther JH. 1962. Studies of marine planktonic diatoms. I. Cyclotella nana and Detonula confervaceae Husted (Cleve) Gran. Can J Microbiol 8:229-239.

23. Riisgard HU, Norgard-Nielsen K, Sogaard-Jensen B. 1980. Further studies on volume regulation and effects of copper in relation 
to $\mathrm{pH}$ and EDTA in the naked marine flagellate Dunaliella ma rina. Mar Biol 56:267-276.

24. Stauber JL, Florence TM. 1989. The effect of culture medium on metal toxicity to the marine diatom Nitzschia closterium and the freshwater green alga Chlorella pyrenoidosa. Water Res 23:907911.

25. Gimmler H, Treffny B, Kowalski M, Zimmermann U. 1991. The resistance of Dunaliella acidophila against heavy metals: The importance of the zeta potential. $J$ Plant Physiol 138:708-716.

26. Robinson NJ. 1989. Algal metallothioneins: Secondary metabolites and proteins. J Appl Phycol 1:5-18.

27. Knauer K, Behra R, Sigg L. 1997. Effects of free $\mathrm{Cu}^{2-}$ and $\mathrm{Zn}^{2-}$ ions on growth and metal accumulation in freshwater algae. En viron Toxicol Chem 16:220-229.

28. Franklin NM, Stauber JL. Lim R. 2000. pH-dependent toxicity of copper and uranium to a tropical freshwater alga (Chlorella sp.). Aquat Toxicol 48:275-289.

29. Stauber JL. 1995. Toxicity testing using marine and freshwater unicellular algae. Aust $J$ Ecotoxicol 1:15-24.

30. Rachlin JW, Jensen TE. Baxter M. Jani V. 1982. Utilization of morphometric analysis in evaluating response of Plectonema boryanum (Cyanophyceae) to exposure to eight heavy metals. Arch Environ Contam Toxicol 11:323-333.

31. Bastien C, Côte R. 1989. Effect of copper on the ultrastructure of Scenedesmus quadricauda and Chlorella vulgaris. Int Rev Gesamten Hydrobiol 74:51-71.

32. Visviki I, Rachlin JW. 1994. Acute and chronic exposure of Dunaliella salina and Chlamydomonas bullosa to copper and cad- mium: Effects on ultrastructure. Arch Environ Contam Toxicol 26:154-162.

33. Baker NR, Horton P. 1987. Chlorophyll fluorescence quenching during photoinhibition. In Kyle DJ, Osmond CB, Arntzen CJ. eds, Photoinhibition. Elsevier, Amsterdam. The Netherlands. pp 145-168.

34. Neale PL, Cullen JJ, Yentsch CM. 1989. Bio-optical inferences from chlorophyll $a$ fluorescence: What kind of fluorescence is measured in flow cytometry? Limnol Oceanogr 34:1739-1748.

35. Samson G, Morissette JC, Popovic R. 1988. Copper quenching of the variable fluorescence in Dunaliella tertiolecta. New evidence for a copper inhibition effect on PSII photochemistry. Photochem Photobiol 48:329-332.

36. Yruela I, Alfonso M, Oritiz de Zarate I. Montoya G, Picorel R. 1993. Precise location of the copper-inhibitory binding site in higher plant and bacterial photosynthetic reaction centers as probed by light-induced absorption changes. J Biol Chem 268 1684-1689.

37. Bentley-Mowat JA. 1982. Application of fluorescence microscopy to pollution studies on marine phytoplankton. Bot Mar 25: 203-204.

38. Regel RH. 1997. The response of Microcystis aeruginosa (Cyanophyceae) to heavy metals and stormwater. Honors thesis. University of Adelaide, Adelaide, SA, Australia.

39. Gilbert F. Galgani F, Cadiou Y. 1992. Rapid assessment of metabolic activity in marine microalgae: Application in ecotoxicology tests and evaluation of water quality. Mar Biol 112:199-205.

40. Berglund DL, Eversman S. 1988. Flow cytometric measurements of pollutant stresses on algal cells. Cytometry 9:150-155. 